\title{
Biopsychosocial Factors of Infertility among Men in Surakarta, Central Java
}

\author{
Devita Agustina'), Uki Retno Budihastuti²), Bhisma Murti1) \\ ${ }^{1)}$ Masters Program in Public Health, Universitas Sebelas Maret \\ 2)Department of Obstetrics and Gynecology, Dr. Moewardi Hospital, Surakarta
}

\begin{abstract}
Background: Impaired fertility affects $7-17 \%$ of all couples. Isolated male factor infertility may occur in $20 \%$ of all infertile couples. One recent study demonstrated a high rate of erectile dysfunction, depressive symptoms, and dysfunctional sexual relationships among male partners of infertile couples. This study aimed to examine the biopsychosocial factors on infertility among men in Surakarta, Central Java.

Subjects and Method: This was a cross-sectional study conducted at Sekar Clinic (Infertility Clinic), Dr. Moewardi Hospital, Surakarta, Central Java, from January to May 2018. A sample of 120 men was selected by fixed disease sampling. The dependent variable was infertility. The independent variables were age, body mass index (BMI), smoking, occupational radiation exposure, stress, and physical activity. Data on infertility were obtained from medical record. The other variables were measured by questionnaire. The data were analyzed by path analysis run on Stata 13.

Results: Male infertility was directly and positively associated with age $\geq 40$ years $(b=1.45 ; 95 \%$ $\mathrm{CI}=0.34$ to $2.49 ; \mathrm{p}=0.010), \mathrm{BMI} \geq 25(\mathrm{~b}=0.98 ; 95 \% \mathrm{CI}=-0.95$ to $2.05 ; \mathrm{p}=0.074)$, smoking $(\mathrm{b}=0.98$; $95 \% \mathrm{CI}=0.57$ to $1.91 ; \mathrm{p}=0.037)$, occupational radiation exposure $(\mathrm{b}=1.63 ; 95 \% \mathrm{CI}=0.52$ to 2.75 ; $\mathrm{p}=0.004)$, and lack of physical activity $(\mathrm{b}=1.11 ; 95 \% \mathrm{CI}=0.13$ to $2.09 ; \mathrm{p}=0.027)$. Male infertility was indirectly associated with stress.

Conclusion: Male infertility is directly and positively associated with age $\geq 40$ years, BMI $\geq 25$, smoking, occupational radiation exposure, and lack of physical activity. Male infertility is indirectly associated with stress.
\end{abstract}

Keywords: infertility, male, smoking, body mass index, occupational radiation exposure, path analysis

\section{Correspondence:}

Devita Agustina. Masters Program in Public Health, Universitas Sebelas Maret, Jl. Ir. Sutami No. 36 A, Surakarta 57126, Central Java. Email: inidevita@gmail.com

\section{BACKGROUND}

Couples or spouses always want the presence of a child who is expected to continue his lineage. There are some couples who are not easily to have children because of several problems. Infertility is a condition where couples are not able to have children despite having sexual intercourse 2-3 times a week, within a period of 1 year without using any kind of contraceptive instrument. Infertility is still one of the most important, serious and worrying issues, since infertility issues are not only a medical problem but also an economic and psychological problem. In the case of female infertility, it has always been the source of the problem, whereas the possibility of infertility not only comes from women alone, but men also participate and have an important role in it (Copen and Stephen, 2013; Polis et al., 2017; WHO, 2016).

Infertility occurs worldwide, 48.5 million couples from all over the world at 
the highest fertility rates in Africa and Europe, 8-12\% was infertile, while in the United States $10 \%$ are infertile due to factors from women and men. According to WHO (2017), the prevalence of infertility still reaches 60-80 million couples worldwide. According to World Population Data Sheet (2013), Indonesia is the fifth country in the world with the largest population with the estimation of 249 millions. Among ASEAN countries, Indonesia with the largest region remains the country with the largest population, far above 9 other countries. Indonesia Fertility rate is 2.6 or still above the ASEAN TFR average of 2.4. Not all couples are fertile, but some couples have infertility. In Indonesia the number of infertility couples of productive age is 12$15 \%$. Infertility is $40 \%$ influenced by men, $40 \%$ is influenced by women and $20 \%$ is influenced by both of them (HIFERI, 2013; Ministry of health, 2014; Kumar et al, 2015; WHO, 2017).

Important biospicosocial models are studied in order to know the importance of forces from outside or from within. Infertility is also influenced by biological, psychological and social factors. As for some of the factors affecting infertility itself because women who are $<30$ years old and men who are $<35$ years old have the highest levels of fertility (Sharma et al., 2013), Body Mass Index was associated with obesity in men. Out of 2384 study subjects, 620 (26 \%) were overweight and 298 (12.5\%) of them were obese and had sperm concentrations that tend to be lower than men with normal BMI (Wang et al., 2017), smoking habits in a study that Sansone et al (2018) had conducted a significant decrease in smokers' sperm concentrations compared with non-smokers, physical exercise, studies conducted by (Durairajanayagam, 2018) shows that $27 \%$ of stress factors are significantly affected by decreased testos- terone levels, occupations involving exposure to harmful substances to fertility, nutritional status affecting the system reproduction, excessive alcohol consumption can cause interference with hypothalamus and pituitary function, polluting or near-industrial environment affecting sperm quality, and educational level (Agarwal et al., 2015; Kazemijaliseh et al., 2015; Peyromusavi et al., 2015).

The purpose of this study was to analyze the relationship of age, BMI, smoking, occupational type, stress, and physical activity.

\section{SUBJECTS AND METHOD}

\section{Study Design}

This was analytic observational study with a cross sectional design. The study was conducted at Sekar Clinic, Dr. Moewardi hospital, Surakarta, Central Java, from January to May 2018.

\section{Population and Sample}

The population in this study was all men who visit the Sekar Clinic and analyzed sperms at Dr. Moewardi hospital. A sample of 120 men was selected by fixed disease sampling, comprising 55 infertile men and 65 fertile men.

\section{Study Variables}

The dependent variable is infertility in men. The independent variables include: age, BMI, smoking habits, occupation, stress level, and physical exercise.

\section{Operational Definition of Variables}

Infertility was defined as a condition in a male within $>1$ year, although having sexual activity 2-3 times in a week without any kind of contraception, they do not have children, and the number, concentration, $\mathrm{pH}$, volume, morphology, and mortality male sperm is less than normal. The data were obtained from medical record. The measurement scale was categorical, coded o for fertile and 1 for intertile. 
Indonesian Journal of Medicine (2018), 3(1): 14-21 https://doi.org/10.26911/theijmed.2018.03.01.02

Age was defined as the age of men when coming to the Sekar Clinic. The data were collected by questionnaire. The measurement scale was continuous, but for the purpose of data analysis, it was transformed into dichotomous, coded o for $<40$ years and 1 for $\geq 40$ years.

Body mass index (BMI) was defined as a weight classification calculated on the basis of height and weight measurement. The measurement scale was continuous, but for the purpose of data analysis, it was transformed into dichotomous, coded o for $<25$ and 1 for $\geq 25$.

Smoking was defined as a person consuming cigarettes. The data were collected by questionnaire. The measurement scale was categorical, coded o for no and 1 for yes.

Occupational type was defined as a form of activity undertaken by research subjects to earn income exposed to chemicals, toxic gases, and radiation. The data were collected by questionnaire. The measurement scale was categorical, coded o for no and 1 for yes.

Stress was defined as a condition in which a person experiences psychological distress. The measurement scale was continuous, but for the purpose of data analysis, it was transformed into dichotomous, coded o for low and 1 for high.

Physical activity was defined as an exercise perform to maintain physical fitness. It was measured by intensity, volume, and frequency. The measurement scale was continuous, but for data analysis, it was transformed into dichotomous, coded o for low and 1 for high.

\section{Data Analysis}

The data were analyzed by path analysis run on Stata 13 to estimate the relationships of the independent variables to the dependent variables.

\section{Research Ethics}

The research ethics included informed consent, anonymity, confidentiality and ethical clearance. The ethical clearance in this study was obtained from Research Ethics Committee, Dr. Moewardi hospital, Surakarta, Central Java, Indonesia, and was declared as worthy of ethics based on decision letter number: 386 / IV / HREC / 2018.

\section{RESULTS}

\section{Univariate Analysis}

Table 1 shows that most of the study subjects aged $<40$ years $(85,70.8 \%)$ and $\mathrm{BMI} \geq 25$ (82, 68.3\%).

Men who smoke were 58 (48.3\%) and those who do not smoke were 62 (51.7\%). Subjects with exposed occupation were 29 (24.2\%) and those who were not exposed were 91 (75.8). Men with stress level $\geq 14$ were $65(54.2 \%)$ and those with no stress $<14$ were 55 (45.8\%). Men with physical exercise <150 minutes/week were 49 (40.8\%) and $\geq 150$ minutes/ week and never did physical exercise were 71 (59.2\%).

Table 1. Univariate Analysis

\begin{tabular}{lcc}
\multicolumn{1}{c}{ Variable } & n & (\%) \\
\hline Infertility & & \\
Infertile & 55 & 45.8 \\
Fertile & 65 & 54.2 \\
Age & & \\
<40 years old & 85 & 70.8 \\
$\geq 40$ years old & 35 & 29.2 \\
Body Mass Index & & \\
>18.5-25 & 38 & 31.7 \\
$\geq 25$ & 82 & 68.3 \\
Smoking habit & & \\
Smoking & 58 & 48.3 \\
Not smoking & 62 & 51.7 \\
Occupation & & \\
Exposed & 29 & 24.2 \\
Did not expose & 91 & 75.8 \\
Stress Level & & \\
Stressed $\geq 14$ & 65 & 54.2 \\
Not Stressed <14 & 55 & 45.8 \\
Physical Exercise & & \\
$<150$ minutes/ week & 49 & 40.8 \\
$\geq 150$ minutes/week & 71 & 59.2 \\
\hline
\end{tabular}


2. Bivariate Analysis

Bivariate analysis was used to observe the association of independent variables (age, BMI, smoking habit, occupation type, stress level, and physical exercise) with the dependent variable (male infertility). The result of bivariate analysis can be seen in Table 2.

Table 2. Bivariate analysis on the factors affected to men infertility

\begin{tabular}{|c|c|c|c|c|c|c|c|}
\hline \multirow{2}{*}{ Dependent Variables } & \multicolumn{2}{|c|}{ Fertile } & \multicolumn{2}{|c|}{ Infertile } & \multirow[t]{2}{*}{ OR } & \multirow{2}{*}{$95 \%$ CI } & \multirow{2}{*}{$\mathbf{p}$} \\
\hline & $n=65$ & $\%$ & $\mathbf{n}=55$ & $\%$ & & & \\
\hline \multicolumn{8}{|l|}{ Age } \\
\hline$<40$ years old & 58 & 68.2 & 27 & 31.8 & 8.59 & 3.34 to 22.12 & $<0.001$ \\
\hline$\geq 40$ years old & 7 & 20.0 & 28 & 80.0 & & & \\
\hline BMI & & & & & & & $<0.001$ \\
\hline$>18.5^{-25}$ & 30 & 78.9 & 8 & 21.1 & 5.04 & 2.06 to 12.32 & \\
\hline$\geq 25$ & 35 & 42.7 & 47 & $57 \cdot 3$ & & & \\
\hline \multicolumn{8}{|l|}{ Smoking } \\
\hline Not Smoking & 44 & 71.0 & 18 & 29.0 & $4 \cdot 31$ & 2.00 to 9.27 & $<0.001$ \\
\hline Smoking & 21 & 36.2 & 37 & 63.8 & & & \\
\hline \multicolumn{8}{|l|}{ Type of Employment } \\
\hline Not Exposed & 59 & 64.8 & 32 & 35.2 & 2.72 & 1.29 to 5.73 & $<0.001$ \\
\hline Exposed & 6 & 20.7 & 23 & 79.3 & & & \\
\hline Stress Level & & & & & & & $<0.001$ \\
\hline Low $<14$ & 37 & 67.3 & 18 & 32.7 & 2.72 & 1.29 to 5.73 & \\
\hline High $\geq 14$ & 28 & 43.1 & 37 & 56.9 & & & \\
\hline \multicolumn{8}{|l|}{ Physical Exercise } \\
\hline <150 minutes/week & 36 & 73.5 & 13 & 26.5 & 4.01 & 1.81 to 8.85 & $<0.001$ \\
\hline$\geq 150$ minutes/week & 29 & 40.8 & 42 & 59.2 & & & \\
\hline
\end{tabular}

\section{Path analysis}

Figure 1 depicted structural model of path analysis with parameter estimates. Men's infertility was directly affected by age, BMI, physical activity, smoking, and employment status. Men's infertility was indirectly affected by stress, smoking, and employment status.

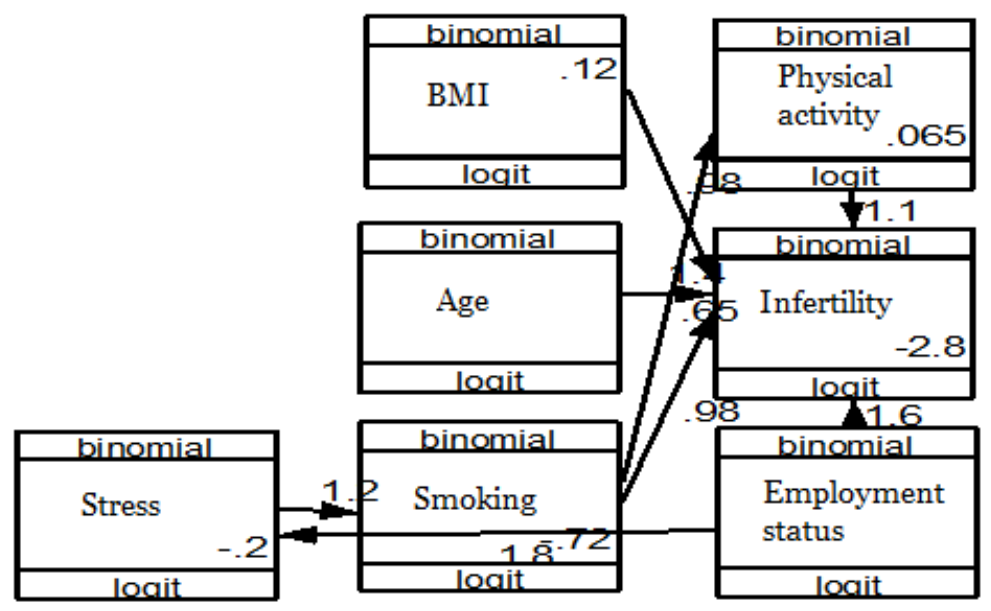

Figure 1. Structural model with parameter estimates

Table 3 showed that there was a significant relationship between age, BMI, smoking habit, type of employment, and physical exercise on men infertility.
Infertility has a positive association with age $(b=1.42 ; 95 \% \mathrm{CI}=0.34$ to $2.49 ; \mathrm{p}=$ 0.010), BMI ( $\mathrm{b}=0.98 ; 95 \% \mathrm{CI}=-0.09$ to 2.05; $\mathrm{p}=0.074)$, smoking habit $(b=0.98$; $95 \% \mathrm{CI}=0.06$ to $1.91 ; \mathrm{p}=0.037$ ), type of 
employment $(\mathrm{b}=1.63 ; 95 \% \mathrm{CI}=0.52$ to 2.75; $\mathrm{p}=0.004)$, physical exercise $(\mathrm{b}=1.11$; $95 \% \mathrm{CI}=0.13$ to $2.09 ; \mathrm{p}=0.027$ )

Physical exercise was positively affected by smoking $(b=0.65 ; 95 \% \mathrm{CI}=-0.86$ to
1.39; $\mathrm{p}=0.083)$. Stress was positively affected by type of employment $(b=1.77$; $95 \% \mathrm{CI}=0.72$ to $2.81 ; \mathrm{p}=0.001)$. Smoking was positively affected by high stress $(\mathrm{b}=$ $1.19 ; 95 \% \mathrm{CI}=0.44$ to $1.94 ; \mathrm{p}=0.002$ ).

Table 3. The result of path analysis on the factors affecting men's infertility

\begin{tabular}{|c|c|c|c|c|c|c|}
\hline \multirow{2}{*}{$\begin{array}{c}\text { Dependent } \\
\text { variables }\end{array}$} & \multirow{2}{*}{\multicolumn{2}{|c|}{$\begin{array}{c}\text { Independent } \\
\text { variables }\end{array}$}} & \multirow{2}{*}{ b } & \multicolumn{2}{|c|}{$95 \%$ CI } & \multirow[b]{2}{*}{$\mathbf{p}$} \\
\hline & & & & Lower Limit & Upper Limit & \\
\hline Direct Effect & & & & & & \\
\hline Infertility & $\leftarrow$ & Age & 1.42 & 0.34 & 2.49 & 0.010 \\
\hline Infertility & $\leftarrow$ & BMI & 0.98 & -0.09 & 2.05 & 0.074 \\
\hline Infertility & $\leftarrow$ & Smoking & 0.98 & 0.06 & 1.91 & 0.037 \\
\hline Infertility & $\leftarrow$ & $\begin{array}{l}\text { Type of } \\
\text { Employment }\end{array}$ & 1.63 & 0.52 & 2.75 & 0.004 \\
\hline $\begin{array}{l}\text { Infertility } \\
\text { Indirect Effect }\end{array}$ & $\leftarrow$ & Physical Exercise & 1.11 & 0.13 & 2.09 & 0.027 \\
\hline Physical Exercise & $\leftarrow$ & Smoking & 0.65 & -0.09 & 1.39 & 0.083 \\
\hline Stress & $\leftarrow$ & $\begin{array}{l}\text { Type of } \\
\text { Employment }\end{array}$ & 1.77 & 0.72 & 2.81 & 0.001 \\
\hline Smoking Habit & $\leftarrow$ & High stress & 1.19 & 0.44 & 1.94 & 0.002 \\
\hline
\end{tabular}

\section{DISCUSSION}

1. The relationship between age and infertility among men

The result of analysis showed that age affected the infertility among men, and it was statistically significant. Men who were $\geq 40$ years old have risk by 1.42 times to have infertility.

The result of this study was in accordance with a study by Eisenberg et al. (2014), which stated that sperm quality was decreased at the age of 40-49 years old. The incidence of infertility was increased at the age of more than 35 years old (Somigliana et al., 2016)

\section{The relationship between BMI and infertility among men}

The result of analysis showed that there was an effect between BMI and infertility among men. Men with BMI $\geq 25$ increased the risk of infertility.

The result of this study was in line with a study by Wang et al. (2017), which stated that someone who was overweight or obese has sperm concentrations and low sperm motility compared to men who have normal weight. In addition, a person with a BMI of $\geq 25$ may inhibit the synthesis of testosterone which can lead to poor sperm quality. Overweight increased the likelyhood of asthenozoospermia and oligozoospermia. BMI and sperm parameters showed that there was a significant relationship between obesity and sperm production (volume, concentration, and amount).

\section{The relationship between smoking habit and infertility among men}

The result of analysis showed that there was an effect between smoking and infertility among men. Smoking increased the risk of infertility.

The result of this study was in accordance with a study by Durairajanayagam (2018), which stated that there was a relationship between smoking habit and infertility among men. Men with smoking habits could disrupt spermatogenesis that affected the sperm quality and DNA damage. 


\section{The relationship between type of employment and infertility among men}

The result of analysis showed that there was an effect between type of employment and infertility among men.

The result of this study was in accordance with a study by Uygungül et al. (2014), which stated that there was a relationship between type of employment and infertility among men. Employment with radiation exposure, a hot environment, exposure to chemicals, and toxic gases could affect the quality of sperm that caused oligozoospermia by 1.8 times and increase the risk by 5.23 times to have teratozoospermia.

The type of employment has a role in the occurrence of the disease through several ways. One of them was the relationship between the work and the disease either directly or indirectly such as exposure to chemicals, toxic, gas, radiation, and no body movement in a job that can lead to diseases, one of them was it can affect the quality of sperm that lead to infertility (Indarwati et al., 2017)

\section{The relationship between physical} exercise and infertility among men

The result of analysis showed that there was an effect between physical exercise and infertility among men. Men with excessive physical exercise and never do physical exercise have risk by 1.11 times to experienced infertility.

Physical exercise was done to improve physical fitness, improve health, and quality of life with the intensity and appropriate volume (Vaamonde et al., 2017). Excessive physical exercise with higher intensity can affected sperm concentration, the amount of sperm, and sperm morphology (Jozkow et al., 2017).

\section{The relationship between smoking habit and infertility among men through physical exercise}

The result of analysis showed that there was an effect between smoking and infertility among men through physical exercise.

A study by Lee and Yi (2016) stated that there was a relationship between smoking habit and physiscal exercise. A smoker was significantly less likely to consume fruits, vegetables, and milk, they also tend to prefer fast food, therefore, it affected his physical exercise.

\section{The relationship between type of employment and infertility among men through stress level}

The result of analysis showed that there was an effect between type of employment and infertility among men through stress.

The result of this study was in line with a study by Lee and Yi (2016), which stated that tasks, workload, time, environment, and work management affected stress, the higher the workload of a person, the higher the level of stress.

\section{The relationship betweeen stress \\ level and infertility among men through smoking habit}

The result of analysis showed that there was an effect between stress level and infertility among men through smoking.

The result of this study was in accordance with a study by Lawless et al. (2015), which stated that a person who experienced stress would affect the smoking habit. Many people believe that smoking can heal the stress (Altunay et al., 2013).

\section{CONFLICT OF INTEREST}

The authors declare that there is no conflict of interest regarding the publication of this article. 
Indonesian Journal of Medicine (2018), 3(1): 14-21

https://doi.org/10.26911/theijmed.2018.03.01.02

\section{REFERENCES}

Agarwal A, Mulgund A, Hamada A, Chyatte

MR. (2015). A unique view on male infertility around the globe, Reproductive Biology and Endocrinology. 13(1): 1-9. doi: 10.1186/s12958-015o032-1.

Altunay I, Doner N, Mercan S, Demirci GT. (2013). Stress coping mechanisms in smoking psoriatics. Dermatologica Sinica. Elsevier, 31(3): 130-133. doi: 10.1016/j.dsi.2013.02.001.

Copen CE, Stephen EH (2013). Infertility and impaired fecundity in the United States, 1982 - 2010: Data From the National Survey of Family Growth. Natl Health Stat Report. 14(67):1-18.

Durairajanayagam D (2018). Lifestyle causes of male infertility. Arab Journal of Urology. Arab Association of Urology, 16(1): 10-20. doi: 10.1016/j.aju.2017.12.004.

Eisenberg ML, Li S, Behr B, Cullen MR, Galusha D, Lamb DJ, Lipshultz. (2014). Semen quality, infertility and mortality in the USA. Human Reproduction, 29(7): 1567-1574. doi: 10.1093/humrep/deu106.

Himpunan Endokrinologi Reproduksi dan Fertilitas Indonesia, Perhimpunan Fertilisasi In Vitro Indonesia, Ikatan Ahli Urologi Indonesia, Perkumpulan Obstetri dan Ginekologi Indonesia. (2013). Konsensus penanganan infertilitas.

Indarwati I, Hastuti URB, Dewi YLR (2017). Analysis of factors influencing female infertility. Journal of Maternal and Child Health, 2(2): 151-162.

Jóźków P, Rossato M (2017). The impact of intense exercise on semen quality. American Journal of Men's Health, 11(3): 654-662. doi: 10.1177/1557988316669045

Kementrian Kesehatan RI (2014). Situasi dan analisis keluarga berencana. pusat data dan informasi.

Kumar N, Singh AK (2015). Trends of male factor infertility, an important cause of infertility: A review of literature. Journal of Human Reproductive Sciences; 8(4): 191-196. doi: 10.4103/0974-1208.170370

Kazemijaliseh H, Tahrani FR, Gandevani SB, Hosseinpanah F, Khalili D, Azizi F (2015). The prevalence and causes of primary infertility in Iran: a population-based study. Global Journal of Health Science, 7(6): 226-232. doi: 10.5539/gjhs.v7n6p226.

Lawless MH, Harrison KA, Grandits GA, Eberly LE, Allen (2015). Perceived stress and smoking-related behaviors and symptomatology in male and female smokers', Addictive Behaviors. Elsevier Ltd, 51: 80-83. doi: 10.1016/j.addbeh.2015.07.011.

Lee B, Yi Y (2016). Smoking, physical activity, and eating habits among adolescents. Western Journal of Nursing Research, 38(1): 27-42. doi: 10.1177/0193945914544335 .

Murti B (2013). Desain dan ukuran sampel untuk penelitian kuantitatif dan kualitatif di bidang kesehatan. Yogyakarta: Gadjah Mada University Press.

(2016). Prinsip dan metode riset epidemiologi. Surakarta: Yuma Pustaka.

Peyromusavi F, Barouni M, Naderi T, Shahravan A (2015). Factors affecting response to infertility treatment: case of Iran. Global Journal of Health Science, 8(1): 118. doi: 10.5539/gjhs.v8n1p118.

Polis CB, Cox CM, Tuncalp O, Mclain AC, Thoma ME (2017). Estimating infertility prevalence in low-to-middleincome countries: An application of a current duration approach to Demo- 
graphic and Health Survey data. Human Reproduction, 32(5): 10641074. doi: 10.1093/humrep/dexo25.

Sharma R, Biedenharn KR, Fedor JM, Agarwal A (2013). Lifestyle factors and reproductive health: Taking control of your fertility. Reproductive Biology and Endocrinology. Reproductive Biology and Endocrinology, 11(1): 1. doi: 10.1186/1477-7827-11-66.

Somigliana E, et al. (2016). Age-related infertility and unexplained infertility: An intricate clinical dilemma. Human Reproduction, 31(7): 1390-1396. doi: 10.1093/humrep/dewo66.

Uygungül E, et al. (2014). Determining risk factors of bleeding in patients on warfarin treatment.
Vaamonde D, Garcia-Manso JM, Hackney AC (2017). Impacto de la actividad física y el ejercicio sobre el potencial reproductivo masculino: nuevo cuestionario de evaluación. Revista Andaluza de Medicina del Deporte. Consejería de Turismo y Deporte de la Junta de Andalucía, 10(2): 79-93. doi: 10.1016/j.ramd.2016.11.017.

Wang E-Y, Huang Y, Du Q-Y, Yao G-D, Sun YP (2017). Body mass index effects sperm quality: a retrospective study in Northern China. Asian Journal of Andrology, 19(2): 234. doi: 10.4103/1008-682X.169996.

World Health Organization (2016). Multiple definitions in infertility. (2017). Obesity and overweight. 